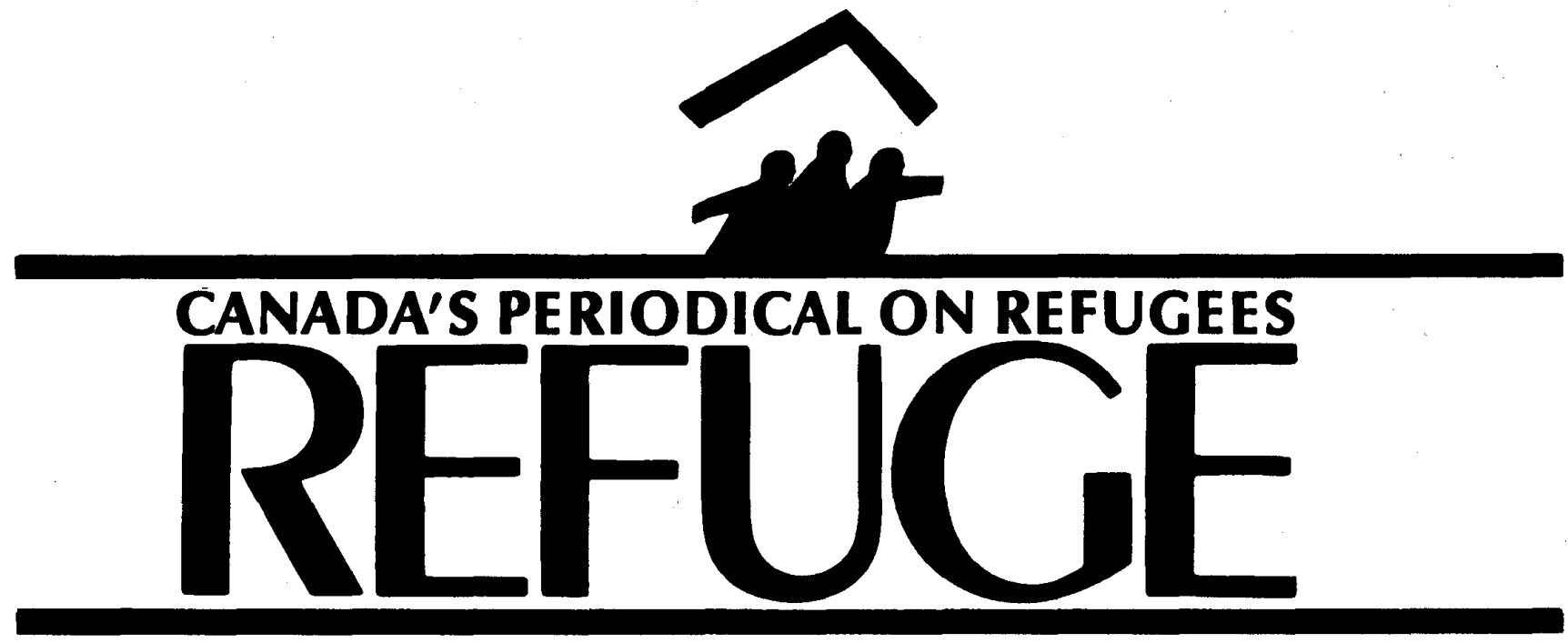

Vol. $14 \cdot$ No. 9

\title{
Focus on SAfe ThiRd Country \\ The Safe Third Country Concept: Deflection in Europe and Its Implications for Canada
}

February 1995

Nazare Albuquerque Abell

This article focuses on the recent emergence of new procedural requirements developed for determination of refugee status which have resulted in apparent violations of applicable international standards. One of those procedural requirements is the "safe third country concept" (STC) developed in Western Europe. The STC concept provides that asylum-seekers coming from a member state of the European Union (EU), or from a third country that is party to the Convention Relating to the Status of Refugees, and the Convention for the Protection of Human Rights and Fundamental Freedoms, may not claim asylum on account of political persecution. The article begins by mapping out the concept of STC and placing it in the context of the broader institutional framework of determining the state responsible for an asylum claim. It examines critically the various repercussions of this concept, and attempts to provide a rationale for its popular acceptance in the Western world. It asks whether the reluctance to grant asylum-seekers permission to enter or to remain in the Western world is compatible with international instruments, such as the 1951 United Nations Convention on the Status of Refugees, ${ }^{1}$ or the 1967 New York Protocol, which supplemented the 1951 Convention. ${ }^{2}$ Finally, in the light of enhanced cooperation in the European Union against asylum-seekers, this article examines and evaluates the new refugee policies of Canada.

\section{Determining the State}

Responsible for an Asylum Claim

The STC has developed in Western Europe, within the EU, as a means to devise more expeditious and accelerated asylum procedures and stricter refugee status criteria, to reduce the overall number of new arrivals, and to prevent the access of asylum-seekers to their territory. The basic principle underlying the STC concept is that the asylum-seeker has already been granted protection in another country, or had an opportunity in another country or at its borders to present an application for asylum. Therefore, it precludes asylum-seekers from presenting several claims in different states. It reflects the idea that asylum should be denied on the grounds that the asylum-seeker already enjoyed,

\section{Contents:}

The Safe Third Country Concept: Deflection in Europe and

Its Implications for Canada Nazare Albuquerque Abell 1

The Demographic Psychosocial Inventory:

A New Instrument To Measure Risk Factors for Adjustment Problems Among Immigrants

Michael Ritsner, Jonathan Rabinowitz and Michael Slyuzberg 


\section{REFUGE}

YORK LANES PRESS Centre for Refugee Studies Suite 351, York Lanes York University 4700 Keele Street, North York Ontario, Canada M3J 1P3 Phone: (416) 736-5843 Fax: (416) 736-5837 Internet: refuge@vm1.yorku.ca

Vol. $14^{\bullet}$ No.9 February 1995

Editor C. MICHAEL LANPHIER Assistant Editors VLADISLAY TUMIR

MARK SWINDER Managing Editor ARUL S. ARULIAH

Refuge is dedicated to the encouragement of assistance to refugees by providing a forum for sharing information and opinion on Canadian and international issues pertaining to refugees. Refuge was founded in 1981.

It is published ten times a year by York Lanes Press for the Centre for Refugee Studies, York University, Canada. Refuge is a nonprofit, independent periodical supported by private donations and by subscriptions. It is forum for discussion, and the views forum for discussion, and the views expressed do not necess

All material in Refuge may be reproduced without permission unless copyrighted or otherwise indicated. Credit should be given to the author or source, if named, and Refuge. Submissions on related issues are welcome for publication consideration.

Current subscription rates for one year (ten issues) are:

Canada Can. $\$ 50$

All other countries U.S. $\$ 60$. (Cheques must be drawn on a Canadian or a U.S. bank.) Single issues are or a U.S. bank.) Single issues
available at $\$ 6.50$ per copy. available at $\$ 6.50$ per copy.
Please enclose your purchase order or Please enclose your purchase order
payment, made payable to York Lanes Press, with your order.

ISSN 0229-5113 could or should have requested and, if qualified, would actually have been granted asylum in another country.

This concept has been developed into a variety of sub-species: "safe country of origin"3 or "countries in which there is generally no serious risk of persecution;" "safe country of transit" or "safe country of return" or, more officially, "host third country." EU member states have also developed another sub-specie called "country of first asylum." It can be found in the Dublin Convention4 and Schengen Agreements.5 It says that the first country within the EU entered by a claimant will accept responsibility for considering the refugee claim. Both agreements, with slight variations, contain rules designed to allocate responsibility for determining the country responsible for an asylum claim. According to these texts, responsibility for consideration of asylum requests is determined as follows:

If the applicant has a visa, the state which issued the visa or, if he has several visas, the state which issued the visa with the longest period of validity, is responsible;

If the applicant has no visa, the first of the member states of the Schengen Agreement or the Dublin Convention at whose frontier the applicant

presents himself is responsible.6

In all cases it means that there is a state considered by other states to be responsible for examining the application for asylum. Some would say it is the state with a special link with the claimant, of the kind that no other state is more appropriate to deal with the request for refugee status.

Furthermore, the third state should be considered "safe." This is a more ambiguous requirement. For most European countries, 'safe' means any country which has signed and ratified the 1951 Geneva convention, or the 1967 New York Protocol and the European Convention for the Protection of Human Rights?

In any case, it is considered that the asylum-seeker should not be sent to a country where his or her life or freedom would be threatened on account of race, religion, nationality, membership in a particular social group, or political opinion, i.e. a country where the asylumseeker is not in fear of persecution according to the terms of Article 1 of the Geneva Convention.8

"Safe third country" appears to simplify and resolve some of the refugee problems of today. First, the asylumseeker can only submit one application for asylum in one member state of the European Union, and if the immigration agreement between Canada and the U.S. is concluded, the asylumseeker can only ask for asylum in one of these two countries. This means that there will be a reduction of asylum claims and therefore a reduction of costs at a time of economic recession in the Western world. Second, the concept operates as commitment to burden-sharing amongs the Western countries. Third, STC insulates the Northern states from refugee flows and, ironically, it allows for an inequitable allocation of the burden of supporting refugees between the North and the South. Countries closest to the site of refugee movements will bear a disproportional responsibility. Finally, according to the states involved in this process, determining the state responsible for an asylum claim will help to differentiate between bona fide refugees and economically motivated migrants, at time when the asylum adjudication systems of wealthy countries are overwhelmed by the mass of economically motivated migrants, who abuse the asylum process

The number of asylum claims has declined significantly in Western Europe. In Germany alone, the number of asylumclaimants dropped by 70 per cent between 1993 and 1994.9 However, that does not mean that the refugee problem is declining; it means that the Western world is succeeding in deterring refugees from seeking asylum in the West.

Dr. Nazare Albuquerque Abell is a postdoctoral researcher at the Refugee Law Research Unit, Centre for Refugee Studies, York University.

Refuge, Vol. 14, No.9 (February 1995) 


\subsection{Repercussions}

First, the application of country of first asylum means that the most restrictive EU practices will became generalized, thus eroding the rights of asylumseekers and reinforcing a lower standard of protection for refugee claimants. When governments compete with one another to keep asylum-seekers out, those that have maintained more generous policies are soon forced to meet the restrictive lowest common denominator, out of fear that they will be left alone to bear the refugee burden as other countries close their borders.

Furthermore, it is a serious violation of human rights to compel an asylumseeker to find refuge in the first country in which he or she sets foot, and strict assignment of responsibilities on the basis of which state authorized entry could lead to rejection of individual claims which, in another state, might have been recognized.

\subsubsection{Violation of the Principle of "Non-Refoulement"}

Second, the use of the STC concept often leads to the breach of a fundamental rule of international refugee law, namely, the principle of non-refoulement. This principle in embodied in article 33 of the Geneva Convention:

No contracting state shall expel or return a refugee (refouler) in any manner whatsoever to the frontiers of territories where his life or freedom would be threatened on account of his race, religion, nationality, membership of a particular social group or political opinion.

The principle of non-refoulement is, beyond any doubt, the main safeguard available to refugees and asylum-seekers, and is regarded as a fundamental principle of public international law.

The STC concept often leads to violation of the principle of non-refoulement because refugees are sent back to so-called "safe" countries, which in turn send them back to the countries they have fled from. A number of Western European countries do not even consider their claims; for example, Spain is one of several countries introducing asylum laws which authorize immediate expulsion for "manifestly unfounded" applications. ${ }^{10}$ The principle of non-refoulement prohibits all ratifying states from taking indirect as well as direct measures of return; otherwise, the phrase "in any manner whatsoever" would be unnecessary.

The principle of non-refoulement must not be confined to prohibition from sending the asylum-seekers back to their country of origin, but must also apply to any other country where they are in danger, particularly because they could not settle there and would be liable to be handed over to the authorities of their own country.

States favouring the STC concept, such as those of the EU, would say that asylum-seekers are not sent back to the countries where they face persecution but to a third country, where the asylum-seeker is protected from refoulement; however, practice has shown that, in some cases, refugees have been sent back to their countries of origin through the use of the STC concept. Furthermore, the states involved have been aware that once the refugees are sent back to certain third countries they will be immediately returned to the countries where they face persecution.

For example, Greece ${ }^{11}$ (a EU member) has been accused of sending back to Pakistan and Turkey (the so-called first countries of asylum) refugees fleeing from Iran, which Turkey and Pakistan then return to Iran. According to Greek law, asylum-seekers are sent back to the first country of passage. On the other hand, Turkey has often declared that it should not be deemed responsible for examining asylum requests merely because of the first entry having been made on its territory, for the purpose of proceeding to another country. 12

The United Nations High Commissioner for Refugees (UNHCR) Executive Committee Conclusions has, in Conclusion No. 58 on irregular movements, accepted that an asylum-seeker may be returned to the country where they had already found protection if the applicant can enter and remain there, is protected against refoulement, and is treated in accordance with basic human rights standards. ${ }^{13}$ In practice, refugees who travelled through countries deemed "safe" are summarily turned back to those countries in blatant breach of Conclusion No. 58. Although the Conclusions are not legally binding on states, one cannot forget that the Executive Committee of the High Commissioner Programme is a body comprised of government representatives from 46 nations to provide guidance in applying the terms of the Convention and Protocol. The purpose of the Conclusions is to ensure consistency on the part of the states when applying the Convention. The Conclusions have been called soft law because they are not legally binding on states; however, because they are approved by consensus, they help to develop the Convention where there is a lacuna, being a legal recourse in certain instances.

Thus, as D. Pretasek has stated, one of the main problems in the existing international system for the protection of refugees is the lack of an effective enforcement mechanism. While the Executive Committee was not explicitly set up to enforce the provisions of the Geneva Convention and Protocol, its past conclusions did indicate some effort to fill this gap. In the absence of any other international body which can point to accepted standards of treatment of refugees and asylumseekers, the Executive Committee is the only available forum, although the latest Conclusions provided a less than hopeful sign of the likely success of such efforts. ${ }^{14}$

The UNHCR also expressed concern about the use of the STC concept in Europe, insofar as shifting the responsibility for examining applications for refugee status to other countries, through which the applicant may have passed, sometimes involves the risk that refugees may be placed in situations that could ultimately lead to refoulement to their country of origin or other places where their life or freedom was threatened. ${ }^{15}$ However, the 
UNHCR is still, to a certain extent, dependent on those same governments for financing, and its appeals have come across as mere exhortations.

\section{The Choice of the Country of Asylum}

When determining the responsibility for examining an asylum request, states do not take into account the intentions of the asylum-seeker. The question is thus the right of an asylumseeker to choose the country of asylum. Some argue that the asylum-seeker does not have a right of choice, and this position is supported by Article 31 of the Geneva Convention, which states:

The Contracting States shall not impose penalties, on account of their illegal entry or presence, on refugees who, coming directly from a territory where their life or freedom was threatened in the sense of Article 1, enter or are present in their territory without authorization, provided they present themselves without delay to the authorities and show good cause for their illegal entry or presence.

Some authors regard this article as showing that the Convention is not based on any rule of free choice of asylum countries, because exemption from penalties in case of illegal entry is dependent upon a direct route from the persecuting country. ${ }^{16}$ This raises the question of what is meant by "directly." Transit through countries lying between the point of departure and the point of arrival, stop-overs in ports or airports, and brief stays with no intention to settle, should not be interpreted in terms of indirect arrival from the country of origin. However, in the EU, under the Schengen and Dublin Agreements it is enough for an asylum-seeker to have spent a few hours in transit at a third country airport to be returned to that country.

Furthermore, compelling an asylum-seeker to find refuge in the first country in which he or she sets foot is a violation of that person's human rights. The main objective of article 31 is to ensure that states would not refuse admission to refugees on the pretext that they had entered its territory ille- gally, which would have endangered the aim of the Convention. Furthermore, nowhere in the Convention is it said that, because asylum-seekers have travelled through a state other than the one of destination, they are precluded from applying for asylum in the state of destination. On the other hand, there is no principle of international law that recognizes foreigners', including asylum-seekers', freedom to settle in a country of their choice; but to impose the opposite principle would be unacceptable.

In practical terms, travelling through a state other than the one of destination might reduce the chances of an asylum-seeker for a successful recognition of refugee status. But it does not mean that the claim is unfounded in terms of the Geneva Convention. The intentions of the asylum-seeker should be taken into account, since he may prefer one country to another for such legitimate reasons as language, family ties, or cultural bonds.

This has been the view taken by the UNHCR EXCom No. $15,{ }^{17}$ which also says that asylum should not be refused solely on the ground that it could have lum-seeker has close family links with the country concerned.

In Canada, the Federal Court has followed this approach. In Charles Kofi Owusu Ansah v. Minister of Employment and Immigration, ${ }^{18}$ the Federal Court reversed the decision of the Immigration and Refugee Board that denied asylum status to a Ghanaian native on the grounds that, before applying for asylum in Canada, he had opportunity to claim asylum status in Togo, Nigeria, and Brazil. The Court declared that the explanations given by the asylum-seeker were credible and sufficient to account for his failure to seek asylum in the three previous countries. ${ }^{19}$

In the EU, and according to the terms of Schengen and Dublin, the asylum-seeker does not have the right to choose the country of asylum. Furthermore, if the first country of asylum declines protection, the asylum-seeker does not have the right to return to the chosen country in the European Union. ${ }^{20}$ For example, in July 1994, a national from Togo, who had arrived at the Munich airport, was sent back to Belgium on the grounds that he had previously spent a few hours in transit

\section{In practical terms, travelling through a state other than the one of destination might reduce the chances of an asylum-seeker for a successful recognition of refugee status. But it does not mean that the claim is unfounded in terms of the Geneva Convention. The intentions of the asylum-seeker should be taken into account, since he may prefer one country to another for such legitimate reasons as language, family ties, or cultural bonds.}

been sought from another state, and that before an applicant for asylum is sent to another country there should be full assurance that the asylumseeker will be admitted and the asylum application examined in fair procedures.

The UNHCR also notes that, in line with the relevant Executive Committee Conclusions, states should take into account any links which the applicant has with them as compared with a third country, and special regard should be given to cases where the asy- . at the Brussels airport en route to Germany and, despite the fact that the applicant had a relative in Germany. In Belgium, he was then denied asylum on the grounds that his claim had been looked at in Germany, and he was removed back to Togo. Unfortunately, this is not the only such case. ${ }^{21}$

\section{The Safe Third Country in Canada}

The process of collective deterrence in Western Europe will necessarily have an effect in Canada. The result may be 
a deflection of claimants from Europe to Canada. Some have said that a fair and open determination system, such as the Canadian, will not be able to cope with the pressures generated by the diminution of asylum opportunities in Europe, and therefore Canada will end up joining the European "club." This argument is based on the fact that Canada is not geographically a country of asylum. Asylum-seekers arrive in Canada via Europe or the United States. Therefore, if conditions in Europe are not favourable for asylum-seekers, there is the belief that they would try to reach Canada where they might be recognized as refugees.

The above argument does not take into consideration the fact that deterrent measures such as strongly enforced visa controls and airline sanctions will deter asylum-seekers from reaching Canada. ${ }^{22}$

Nevertheless, Canada has pursued this topic in diplomatic forums. These include the Intergovernmental Consultations on Asylum, Refugee and Migration Policies in Europe, North America and Australia, which comprises 13 European governments, Canada, Australia, and the United States. The Consultations largely focus on removals, prevention of asylumseeking, and information sharing on individuals seeking asylum in order to avoid asylum shopping. In this regard, the Minister of Immigration and Citizenship has now the right to forge agreements with other states for the "purposes of facilitating the coordination and implementation of immigration policies and programs." ${ }^{23}$

Under the recent amendments, Bill $\mathrm{C}-86$ made provisions allowing the government to prescribe a country as a STC. ${ }^{24}$ Thus, at the first stage of a hearing for refugee status, the panel (a member of the Convention Refugee Determination Division and an Immigration Adjudicator) may refuse a claim if the asylum-seeker can return to a safe third country. This could affect asylum-seekers who came to Canada after spending time in a first asylum country in Europe or in the United States..$^{25}$ Bill C-86 sets forth the conditions for the prescription of a country as a STC to allow Canada to send asylum-seekers back to that country without an examination of the claim if the claimant arrived such a route.

Paragraph 114(1)(s) permits the Governor in Council to prescribe a country as a STC. The conditions for prescribing a safe third country are:

1. Whether the country is a party to the Convention;

2. The country's policies and practices with respect to Convention Refugee claims;

3. The country's record with respect to human rights;

4. Whether the country is a party to an agreement with Canada concerning the sharing of responsibility for examining refugee claims, notwithstanding that this factor is not a requirement for a country to be prescribed.

In addition, the Governor in Council is required to monitor activities in prescribed countries. Most important, the state must demonstrate incontestable evidence of strict adherence to the principle of non-refoulement. Clearly, the Canadian system of STC, if implemented, would be fairer that the European one.

Safe third countries have not yet been listed by Canada. The problem in listing STCs is that involves an a priori determination about the conditions in these countries vis-à-vis asylum-seekers. For example, can Canada consider the US a safe country, especially in view of its policy towards the Haitian asylum-seekers ${ }^{26}$ and its track record in denying asylum to certain nationalities? But, at the same time, is Canada in a position not to consider it safe? To a certain extent, the STC provisions in the United States are far more generous to the claimant than those proposed in the Canadian legislation and in the EU. In the United States, the criteria for determining a STC are dependent on the fact that the asylum-seeker was firmly settled in another safe country, and did not simply sojourn there or merely had an opportunity to claim refugee status.
Furthermore, the onus of proof is on the state and not on the asylum-seeker.

Gordon Fairweather, former chairmen of the Immigration and Refugee Board, explained the non-implementation of the STC provision in Canada as reflecting recognition that unilateral measures were unlikely to work, and that such measures are not conducive to good neighbourliness or effective, international co-operation in the resolution of problems of refugees and asylum-seekers. ${ }^{27}$

\subsection{The Canada-U.S. Memorandum of Understanding for Cooperation in the Examination of Refugee \\ Status}

While Canada has not listed safe third countries, it has forged a bilataral administrative agreement with the United States, the Memorandum of Understanding (MOU). ${ }^{28}$ The agreement would prevent asylum-seekers from transiting through one country to apply for asylum in the other.

The MOU has been described as placing Canada in a position to ensure better and faster protection for those who choose Canada as their first country of asylum, ${ }^{29}$ and ensuring that the cost of refugee determination will not be wasted on someone "taking two kicks at the can." ${ }^{\prime 30}$ From a practical point of view, due to Canada's geographic position, few would be able to choose Canada as their first country of asylum; one-third of the asylum-seekers coming to Canada arrive via the US.

Currently, asylum-seekers entering Canada from the United States can be turned back if they have resided there. Under the MOU, arriving from the United States would in itself be sufficient ground to turn the claimant back.

The Canadian Council for Refugees has been extremely critical of the MOU, especially because of the U.S. policy towards the Haitians, the fact that the United States is not bound by as many international human rights treaties as is Canada, and the fact that many refugee claimants have fled regimes that have historically been supported by the United States and may 
have legitimate reasons not to wish to ask for refugee status there. ${ }^{31}$

The MOU is significant because it shows that Canada is interested in establishing bilateral agreements in order to protect its territory from large numbers of asylum-seekers. Furthermore, it has been estimated by Canadian and U.S. officials that, under current circumstances, up to 10,000 asylum-seekers would be affected by this new rule, and thus would be required to submit their claims through the US asylum procedure instead of the Canadian one. ${ }^{32}$

One of the main consequences is also the fact that, once an asylumseeker who had previously had a refugee status claim determined by one of the Parties makes a claim in the territory of the other Party, that person will be returned to the country where the initial determination was made. This means that a person denied status in one of the countries in question is to be returned to that country for enforcement of the prior denial. This may provoke an increase in false documentation, asylum-seekers destroying their documents, and illegal entry, in order to get asylum status in Canada. Furthermore, the MOU may lead to indirect refoulement because of the American authorities' strict interpretation of non-refoulement, such as in the case of the Haitian refugees. Family reunification and ties should also be acknowledged. The current version of the draft Memorandum fails to recognize international standards of family reunification.

\section{Conclusions}

There are both a lack of uniformity in the application of the Geneva Convention and a breakdown of the consensus on which the international refugee system was built. States' current interests are to limit the number of refugees and, if possible, to prevent asylum-seekers from reaching their frontiers. This state of affairs is reflected in the use of the STC concept, and in the increasingly restrictive interpretation of the Geneva Convention, straying from its humanitarian spirit. The original objective of the Geneva Convention has been violated, as well as that of other human rights treaty obligations, such as the Declaration of Human Rights, where article 14(1) states that everyone has the right to seek and to enjoy in other countries asylum from persecution. Furthermore, the cardinal principle of non-refoulement is being flouted in some parts of the world by those very states which created and have supported the Geneva Convention.

Apparently, the Safe Third Country concept is here to stay. Therefore, serious efforts should be put into harmonizing it with the principles of international refugee law, the spirit of the Geneva Convention, and international human rights law, which protect asylum-seekers.

\section{Notes}

1. 189 U.N.T.S. 2545 , entered into force April 22, 1954 [hereinafter Geneva Convention].

2. 606 U.N.T.S. 8791, entered into force on October 4, 1967.

3. The member states of the EU have determined by law countries where the occurrence of persecution on political grounds or of inhuman or degrading punishment or treatment is unlikely. A national from one of those countries is considered as not being persecuted on political grounds, and is therefore precluded from invoking the right of asylum. The classification of a country as "safe" is a matter of governmental discretion in each member state of the EU and not subject to any public control.

4. The Dublin Convention is a multilateral Convention for Determining the State Responsible for Examining Applications for Asylum Lodged in One of the Member States of the European Community [text in 2 I.J.R.L. 469 (1990)]. It is an intergovernmental Convention acceded to by the twelve members of the European Community. Because it was deliberately created outside the supranational framework of the EU, there is no jurisdiction either for the EU Court of Justice or for any other international court. Furthermore, it falls outside the competence of the EU Parliament. Thus, there is a lack of democratic and judicial control.

5. Convention Applying the Schengen Agreement of 14 June 1985 Between the Governments of the Benelux Economic Union, the Federal Republic of Germany and the French Republic on the Gradual Abolition of Checks at their Common Borders, June 19, 1990 [text in 3 I.J.R.L. 773 (1991)]. Italy, Portugal, and Spain have signed both Schengen Agreements. The Convention covers detailed arrangements for improved police co-operation, for common visa policies, for data transmission, and for data protection.

The Schengen Agreements are, as the Dublin Convention, characterized by the lack of democratic and judicial control.

6. Both the Dublin Convention and the Schengen Agreements do not attempt to coordinate the different laws on asylum of the EU Member States. Their purpose is limited to the elimination of successive and duplicated applications in various member states of the EU. This is based on the premise that all EU members are contracting parties to the 1951 Convention on the Status of Refugees or the New York Protocol, and thus every applicant who applies in the territory of the EU will be given a fair chance.

7. The European Convention for the Protection of Human Rights and Fundamental Freedoms of 4 November 1950 is probably the best-known European treaty. Its effectiveness is largely due to the provisions of Article 25, which allows "any person, non-governmental organization or group of individuals claiming to be the victim of a violation by one of the High Contracting Parties of the rights set forth in this Convention" to lodge a petition with the Commission addressed to the Secretary General of the Council of Europe in Strasbourg.

8. Article1(A)(2) of the Geneva Convention, as amended by the New York Protocol, defines a refugee as any person who "...owing to well-founded fear of being persecuted for reasons of race, religion, nationality, membership of a particular social group or political opinion, is outside the country of his nationality and is unable, or owing to such fear, is unwilling to avail himself of the protection of that country; or who, not having a nationality and being outside the country of his former habitual residence as a result of such events is unable or, owing to such fear, is unwilling to return to it."

9. "Fortress Europe?" Circular Letter No 30. December 1994/January 1995, at 2.

10. Ibid.

11. Greece has been accused of deporting more than 70,000 refugees to country of their persecution: Ibid.

12. See "Draft Agreement on responsibility for examining asylum requests," Ad Hoc Committee of Experts on the Legal As- 
pects of Territorial Asylum, Refugees and Stateless Persons. (CAHAR) Strasbourg, 25 January 1989. E 14.547 at 4. Four Iranians were sent to Iran after being returned to Turkey by West Germany to where they had been returned by Denmark. In Joly \& Nettleton, Refugee in Europe. The Minority Rights Group, October 1990, at 14.

13. Conclusions on the International Protection of Refugees. Adopted by the Executive Committee of the UNHCR Programme. Published by the Office of the UNHCR. The full text of Conclusion 58 (f) states:

Where refugees and asylum-seekers nevertheless move in an irregular manner from a country where they have already found protection, they may be returned to that country if

i.) they are protected there against refoulement and

ii.) they are permitted to remain there and to be treated in accordance with recognized basic human standards until a durable solution is found for them. Where such return is envisaged, UNHCR may be requested to assist in arrangements for the readmission and reception of the persons concerned;

14. Petrasek, D. "The 44th Session of the UNHCR Executive Committee: A View from the Side." I.J.R.L. Vol. 6 (1), 1994, at 65.

15. U.N. Doc E/1993/20, 26 April 1993, at 7-8.

16. See K. Hailbronner. “The Concept of 'Safe Country' and Expeditious Asylum Procedures." I.J.R.L., 5 (1), 1993, at 58-59. Milander, G. "Refugees in Orbit" A.W.R. Bull. Vol. 16, 1978, at 60 .

17. Part of Conclusion $15(\mathrm{~h})$ reads:

An effort should be made to resolve the problem of identifying the country responsible for examining an asylum request by the adoption of common criteria. In elaborating such criteria the following principles should be observed:

(i) The criteria should make it possible to identify in a positive manner the country which is responsible for examining an asylum request and to whose authorities the asylum-seeker should have the possibility of addressing himself;

(ii) The criteria should be of such character as to avoid possible disagreement between States as to which of them should be responsible for examining an asylum request and should take into account the duration and nature of any sojourn of the asylum-seeker in other countries;

(iii) The intentions of the asylum-seeker as regards the country in which he wishes to request asylum should as far as possible be taken into account;

(iv) Regard should be had to the concept that asylum should not be refused solely on the ground that it could be sought from another State. Where, however, it appears that a person, before requesting asylum, already has a connexion or close links with another State, he may if it appears fair and reasonable be called upon first to request asylum from that State.

18. Federal Court of Appeal Decision A1265-87. See Hathaway, The Law of Refugee Status, Butterworths Canada Ltd. 1991, at 46-50.

19. Owusu Ansah explained that he did not ask for asylum in Togo due to the fear of being kidnapped by Ghanaian authorities, in Nigeria due to the political instability of the government, and in Brazil because he did not speak the language.

20. The European Consultation on Refugees and Exiles (ECRE), a forum for cooperation between more than 50 nongovernmental organizations in Western Europe concerned with refugees and the rights of asylum, has repeatedly spoken against this state of affairs in Europe, recommending that, as a minimum, European States should:

i. before taking a decision to return an asylum applicant to another state, take into account as far as possible the intentions of the asylum seeker as regards the state in which s/he wishes to request asylum;

ii. after taking the decision to return an asylum applicant to another state:

a) inform the applicant, in a language $\mathrm{s} /$ he understands, of the decision to transfer him/her to that other state;

b) provide the applicant with an opportunity to appeal, with suspensive effect, to an independent body against the decision to transfer him/her to another state.

iii) not return an asylum seeker to another state before determining that the following requirements are fulfilled:

a) the receiving state is party to the 1951 Geneva Convention and the 1967 New York Protocol, and complies with the UNHCR Executive Committee Conclusions;

b) the applicant will be admitted to the receiving state under conditions of safety and respect for the individual;

c) the applicant will be protected by the receiving state against refoulement in the meaning of Article 33 of the 1951 Geneva Convention; d) the applicant will be provided by the receiving state with full access to a fair and efficient refugee determination procedure;

e) the applicant will be treated by the receiving state in accordance with human rights standards and international principles of refugee protection.

21. See ECRE, Provisional Report on the Safe Third Country Monitoring Project, 1994.

22. See Hathaway, J. "The Conundrum of Refugee Protection in Canada:From Control to Compliance to Collective Deterrence." In Refugees and the Asylum Dilemma in the West. Ed. by Gil Loescher, 1992; Joly, D. "The Porous Dam: European Harmonization on Asylum in the Nineties." I.J.R.L. Vol. 6 (2), 1994.

23. "108.1 The Minister, with the approval of the Governor in Council, may enter into agreements with other countries for the purpose of facilitating the coordination and implementation of immigration policies and programs including, without restricting the generality of the foregoing, agreements for sharing the responsibility for examining refugee claims and for sharing information concerning persons who travel between countries that are parties to such agreements." Immigration Act c. 49 , s.98

24. See Immigration Act, R.S.C. ch. 1-2, amended by ch.49, 1992, 46.01, 114(1)(s).

25. See the Immigration Act, as modified by Bill C-86, ss. 46.01, 114(1)(s).

26. See the "Haitian Refoulement Case" I.J.R.L. Vol. 6 (1), 1994.

27. In Hailbronner, supra note 16 , at 41.

28. At the time of writing, the MOU was not yet signed, but according to media reports its signature may be imminent. See the Toronto Globe \& Mail, Tuesday, February $14,1995$.

29. See "Canada Tightening Refugee Law, Takes Step Toward Turning Asylum Seekers Back to the U.S." Refugee Reports, September 30, 1992. At 7.

30. Words by Sergio Marchi, Minister of Immigration and Citizenship, in an inter view for The [Toronto] Globe \& Mail, Feb. 14, 1995.

31. See Canadian Council for Refugees, Resolution 23, June 1994

32. See Refugee Reports, supra note 29 , and Helton, A. "Toward Harmonized Asylum Procedures in North America: The Proposed United States-Canada Memorandum of Understanding for Cooperation in the Examination of Refugee Status Claims from Nationals of Third Countries." Cornell Int'1 L. J., 26, 1993. ᄀ 